\title{
The Effect of Problem Posing and Problem Solving Model on Chemistry Learning Outcome
}

\author{
Rilia Iriani and Nor Hidayah \\ Chemistry Education Department, Faculty of Theacher Training Education \\ Universitas Lambung Mangkurat \\ Banjarmasin, Indonesia \\ riliairiani15@gmail.com
}

\begin{abstract}
This study was aimed to determine differences in learning achievements and to find out the most effective learning model among the problem posing, problem solving, and problem posing-solving models in grade X SMAN 6 Banjarmasin. This research used a quasi-experimental methods with a pretestposttest comparison group design. The samples were class X MIA 1 as an experimental class 1, X MIA 2 as an experimental class 2, and $X$ MIA 3 as the experimental class 3. A test-technique was used to collect data and the data were analyzed using one-way Anova test, N-gain test and Duncan test to analyze the cognitive achievement of students who learn chemistry using problem posing, problem solving, and problem posing-solving learning models.The results showed that (1) there were significant differences in cognitive learning achievements among students in the experimental class 1, experimental class 2 and experimental class 3. (2) the use of the learning model problem posing-solving was more effective when applied to the learning process compared to the problem posing model and problem solving model.
\end{abstract}

Keywords-Cognitive Achievement, Mole Concept, Problem Posing, Problem Solving, Problem Posing-solving

\section{INTRODUCTION}

Chemistry is one of the choices of interesting learning subjects in Mathematics and Natural Sciences which studies the chemistry substances beneficial to people's life. Many of everyday natural events can be studied in chemistry, but so far there have been many problems in the learning of chemistry. One of the reasons which gives an impression that chemistry is difficult is that the concept of chemistry is abstract, like learning a new language, chemistry has specific vocabularies.

The topic of the concept of mole in the study of chemistry in the X class of SMA is one of the subjects which comprises the learning of counting which needs the right understanding on the concept. The concept of mole introduces the basis of the chemistry counting. This material consists of concepts and counting which are considered to be difficult to be learned by students and that is why it needs a suitable learning model to introduce.

One of the efforts to increase students' success is by using active learning, most of which processes are done by the students. They should think to do their learning, introduce their ideas, and solve their problems. Also, they should able to apply the material they have learned. They should actively learn to listen, to see, to raise questions on certain topics and then discuss them with the others. Besides that, the most important thing in active learning they should solve problems, find examples, and implement the skills of doing assignments by themselves. These depend on the knowledge they have or will achieve [1]

There are learning models which can improve students' thinking skills in solving problems; these are learning models of problem posing and problem solving. The learning models of problem posing and problem solving are two among the many learning models which involve students' activities and their creativities in their learning process. The two learning models enable them to be active, and enhance their critical thinking and creative skills. The learning models are expected to develop students' positive attitudes in order to develop human resources to face future with more challenges.

The learning model of problem posing is the learning model which requires students to make their own questions or to solve a problem to make simpler questions [2]. This learning model is adapted to students' ability, develop the cognitive structure, and motivate students to think critically.

The learning model of problem solving is the learning process which demands students to solve problems created by the teacher himself/herself, or to solve the problems based on the facts in the surroundings through the learning process in class using many ways and techniques. This model can stimulate students to critically and creatively think, starting from looking for data up to formulating solution so that students can take meaning from the learning activity [2]

The two models are similar in focusing on problem solving; students are invited to be active so that information does not come only from the teacher but also from students. They are also expected to construct new knowledge by themselves based on the available information and their prior knowledge. The difference between the two is that the problem posing learning model enables the students to offer the learning problem; and that the problem solving learning model requires the teacher to offer the learning problem.

The result of a research conducted by [3] states that the use of problem posing learning model results higher learning achievement than that of problem solving one. [4] that the implementation of problem posing learning model completed 
with the material in power point can increase students' achievements. Besides that, [5] shows that there are differences in critical thinking skills, logical-mathematical intelligence and the students' mastery on the concepts on the salt hydrolysis taught by using the problem solving learning model from those who are taught by using the conventional one.

Based on the above explanation, the two models were integrated together in this research to get better result. The integration of the two models becomes a new learning innovation known as the problem posing-solving learning model. By using the problem posing learning model, the students can be more active and are able to construct knowledge through thinking process and by using the problem solving learning model, the students are able to think to solve problems. The integration of the two learning models were conducted as a way to increase students' learning achievement, especially in the concept of mole in chemistry.

\section{METHODS}

This research was conducted through the quasi eksperiment method with the design of pretest-posttest comparison group design. A pretest was given to the sample to find out the students' initial understanding on the concept of mole before the treatment. After the implementation of the problem posing, problem solving, and problem posing-solving models, the postest was given to find out the students' cognitive learning achievement

The population in this research were students of Class XMIA SMA Negeri 6 Banjarmasin Academic Year 2015/2016, the sample of those were Class X MIA 1 as the first $\left(1^{\text {st) }}\right.$ experimental class, Class X MIA 2 as the second $\left(2^{\text {nd }}\right)$ experimental class, and Class X MIA 3 as the third $\left(3^{\text {rd }}\right)$ experimental class, each of those comprises 35 students. The sampling technique used in this research was cluster random sampling. Cluster random sampling is a technique of sampling randomly [6].

The research instrument was a test of cognitive learning achievement consisting of essay test each of which were 7 problems. To get a valid test result a validation test was conducted before hands. The validity was determined based on the evaluation and consideration of three validators: three chemistry lecturers of FKIP ULM Banjarmasin and two chemistry teachers from SMAN 6 Banjarmasin. Result of the counting process using CVR equation, CVR (Content Validity Ratio) was $=1$. It showed that the instrument of the cognitive learning achievement was valid to be used [7]

To find out the reliability of the instrument, before being used, the instrument was tried out. The use of Alpha Cronbach formula showed that the degree of the test instrument was 0 , 85: the instrument was in the high category reliability.

The technique of data analysis was conducted using the descriptive and inferential data analysis. The inferential analysis used in this research was one-way Anava and advanced analysis using Duncan test of Factual Distance Difference. The condition in applying one-way Anava are normality and homogenity of the data. This test was used in order to find out whether there were differences resulted among the first, second and third experimental groups.

\section{RESULT}

The research result on the percentage of students' completeness and the $\mathrm{N}$-gain of cognitive learning result can be seen in Table 1 and Table 2

TABLE I. THE PERCENTAGE OF STUDENTS' COMPLETENESS

\begin{tabular}{|c|c|c|c|}
\hline Score & Experiment 1 & Experiment 2 & $\begin{array}{c}\text { Experiment } \\
\mathbf{3}\end{array}$ \\
\hline $\begin{array}{c}<75 \text { (Not } \\
\text { Complete) }\end{array}$ & 10 & 18 & 24 \\
\hline$\geq 75$ (Complete) & 25 & 17 & 11 \\
\hline $\begin{array}{c}\text { Class } \\
\text { Completeness } \\
(\%)\end{array}$ & 71,43 & 48,57 & 31,43 \\
\hline
\end{tabular}

TABLE II. THE INTERPRETATION OF N-GAIN OF STUDENTS’ LRARNING OUTCOME

\begin{tabular}{|c|c|c|}
\hline Class & $\begin{array}{c}\text { Average } \\
\boldsymbol{N} \text {-gain }\end{array}$ & Criteria \\
\hline Experiment 1 & 0,72 & High \\
\hline Experiment 2 & 0,61 & Medium \\
\hline Experiment 3 & 0,49 & Medium \\
\hline
\end{tabular}

Based on Table 1 and Table 2 it can be found out that the completeness percentage and the average $\mathrm{N}$-gain of the cognitive learning result of students in the experimental class 1 is higher than experimental class 2 and experimental class 3 . It shows that problem posing-solving used for the experimental class 1 is more effective in the learning process than that of the models implemented in the experimental class 2 and experimental class 3 .

The result of the one-way Anava test and the advanced test can be seen in Table 2 and Table 3.

TABLE III. THE RESULT OF ONE-WAY ANAVA IN THE POSTTES SCORE

\begin{tabular}{|c|c|c|c|c|c|c|}
\hline Source & Jk & Db & Rk & Fcount & $\mathbf{F}_{\text {tabel }}$ & Interpretation \\
\hline $\begin{array}{c}\text { Among } \\
\text { Groups }\end{array}$ & 5529,58 & 2 & 2764,79 & & & \\
\hline $\begin{array}{c}\text { In } \\
\text { Groups }\end{array}$ & 21666,85 & 102 & 212,42 & & 3,09 & Significant \\
& 27196,43 & 104 & - & - & - & \\
\hline
\end{tabular}

TABLE IV. DUNCAN TEST RESULT

\begin{tabular}{|c|c|c|c|c|}
\hline \multirow{2}{*}{ Class } & \multirow{2}{*}{ N } & \multicolumn{3}{|c|}{ Subset for alpha $=\mathbf{0 . 0 5}$} \\
\cline { 3 - 5 } & & $\mathbf{1}$ & $\mathbf{2}$ & $\mathbf{3}$ \\
\hline Experiment 3 & 35 & 59,46 & & \\
\hline Experiment 2 & 35 & & 69,91 & \\
\hline Experiment 1 & 35 & & & 77,14 \\
\hline \multicolumn{2}{|c|}{ Sig. } & 1,00 & 1,00 & 1,00 \\
\hline
\end{tabular}

Table 3 and Table 4 show that there was a significant difference among the Experiment Class 1, Experiment Class 2 and Experiment Class 3 to the cognitive learning result. The average of problem posing-solving class was higher than the average of problem posing and problem solving class. It 
showed that there was an effect of the problem posing-solving to students learning achievements.

\section{DISCUSSION}

Based on the Duncan test result, $\mathrm{H} 1$ is accepted or there is a significance difference among the students' cognitive learning result in learning using the problem posing-solving model, the problem posing model and using the problem solving model only. The difference in students' achievement is caused by the implementation of the problem posing-solving learning model. This is in compatible with the research of [8] about the learning of problem posing completed with "LKS" which can increase the students' achievement. Besides that, the test result is also suitable with research done by [9] about the implementation of the problem solving model which can increase students' learning result.

That significant difference also shows that the learning achievements using the problem posing-solving model is higher than the learning achievements using the problem posing model and the achievements of the problem posing model is higher than the learning achievements using the problem solving model. This is parallel with research done by [3] which states that there is significant difference in the learning achievements between using learning using the problem posing and problem solving models. The difference of average cognitive scores is assumed to be appropriate to be used for learning the concept of mole with the problem posing learning model. The material of the concept of mole is a chemistry material which require the understanding of concept better, moreover several sub chapters in this material are abstract and full of calculation.

The model of problem posing itself requires students to learn repeatedly, by self-learning from different sources, and then from the teacher's explanation and learn from an experience of making problems and questions with the solutions. To make problems or questions students are required to understand the material of the concept of mole deeply, whereas in in the problem solving model, students only learn from the teacher and other source without having experience in making problems or problems and solutions. The repeated learning process and students' experience in making problems and problems and solutions experience in the problem posing learning model, makes students understand more with the material of the conc3pt of mole and this material will stick harder to the students. In the use of problem posing learning model, students' also have more experience in solving problems so that their ability in solving problems also higher than students using the problem solving model of learning.

This research is parallel with the research done by [10] which states that problem posing learning model is effective for increasing the ability to solve students' problems. During the learning process of learning using the problem posing model, more students are active in asking or answering questions compared to students using the problem solving learning model. This research is also parallel with research done by [11] which states that cognitive learning achievements which are given by the use of "PBL" using problem posing learning model is better than students given learning with "PBL" which use the problem solving model.

The problem posing-solving learning model is learning which requires students to make problem. Students must have self-learning, so that they must be able to develop their creativity in making problems. According to the theory of constructivism which states that a teacher does not only give knowledge to the students, but also helps students to do selfknowledge construction. The problem solving learning model can increase students' social interaction in a group because it requires students to solve problems from other groups. Besides, to solve problems done by the students, the steps given by the teacher must be used by the students by the use of problem solving.

The two learning models are also suitable to the learning theories of Jean Piaget, Vygotsky, and Ausubel which state that students must be active developing their own knowledge, knowledge will grow from experience with friends of the same age and students must be able to relate new knowledge with the former knowledge. The problem posing-solving learning model requires students to learn individually and in groups to grow students' knowledge about the concept of mole by making problems and solve them base on the steps given by the teacher.

The influence of the problem posing-solving model gives contribution in increasing the cognitive learning results. The increase can be seen from the achievement of the $N$-gain average of the experiment class 1 which is higher than in the experiment class 2 and the class experiment 3 . The average $N$ gain o experiment class 1 gain increase which is classified to the high category.

In this research the completeness percentage gained is $71.43 \%$ in the experiment class $1,48.57 \%$ in the experiment class 2 and $31.43 \%$ in the experiment class 3 . This shows that in the experiment class 2 and experiment class 3 , the classical completeness is lower than $70 \%$, which means that the teacher have not been successful in the learning process and they are not suggested to use the learning model. For experiment class 1 , on the other hand, which classical completeness is more than $70 \%$, which means that the __ 14 learning in this class is stated to be successful and for schools which uses classical completeness of $70 \%$ can use the learning model especially in the material of the concept of mole. The use of the problem posing-solving learning model is more effective to be used in the learning activity than using only the problem posing model or the problem solving model only. This is also shown in the achievement of completeness in classes which implement the problem posing-solving learning model more than he school completeness in that school, which is $70 \%$ or the school completeness and $71,43 \%$ for the completeness of implementation of that learning model.

\section{CONCLUSION AND SUGGESTION}

Based on the research result and discussion it is concluded that (1) there is a significant difference of cognitive learning result of students learning using the problem posing, problem solving, and problem posing-solving in the material of the 
concept of mole; (2) The use of the problem posingsolving learning model is more effective implemented to the learning process of the problem posing- solving learning process than the problem posing and the problem solving learning models.

The researcher's suggestions based on the result of the research, among others, are: (1) other teachers or education staff, especially chemistry teachers better consider the implementation of problem solving model assisted by interactive media to develop "KGS" and optimized the students' learning result besides using the real practicum., (2) the candidate researchers are suggested to use problem solving learning model assisted by the other interactive media by studying all the students KGS indicators other than which is done in this research, (3) the development of KGS better uses interactive media suited to the KGS indicators which will be developed.

\section{REFERENCES}

[1] M. L. Silberman, Active Learning 101 Strategi Pembelajaran Aktif, Yogyakarta: Insan Madani, 2001.

[2] A. Shoimin, 68 Model Pembelajaran Inovatif dalam Kurikulum 2013, Yogyakarta: Ar-ruzz Media, 2014.

[3] Y. Koeswardhani, B. Mulyani and M. Masykuri, "Pengaruh model pembelajaran Problem Solving dan Problem Posing pada pokok bahasan Konsep Mol terhadap prestasi belajar siswa Kelas X semester genap SMA Negeri 6 Surakarta tahun pelajaran 2014/2015," Jurnal Pendidikan Kimia (JPK), vol. 4, no. 1, pp. 38-43, 2015.

[4] M. Y. Ghufroni, H. and B. Hastuti, "Upaya meningkatkan prestasi belajar dan interaksi sosial siswa melalui penerapan metode pembelajaran Problem Posing dilengkapi media power point pada Materi Stoikiometri kelas X SMA Batik 2 Surakarta tahun pelajaran 2012/2013," Jurnal Kimia, vol. 2, no. 3, pp. 114-121, 2013.

[5] S. Rahmini, "Pengaruh Model Problem SOlving Terhadap Peningkatakan Keterampilan Berpikir Kritis dan Kecerdasan Logis Matematis Siswa Pada Pembelajaran Materi Hidrolisis Garam Kelas XI IPA SMA Negei 2 Banjarmasin Tahun AJaran 2012/2013," FKIP Unlam, unpublished, Banjarmasin, 2012.

[6] Sugiyono, Metode Penelitian Pendidikan Pendekatan Kuantitatif, Kualitatif, R \& D, Bandung: Alfabeta, 2012.

[7] R. J. Cohen, Psychological Testing and Assesment, New York: McGraw-Hill, 2010.

[8] L.B. Suryani, A. N. C. Saputro and K. S. Martini, "Implementasi model pembelajaran Problem Posing dilengkapi LKS untuk meningkatkan kemampuan analisis dan prestasi belajar materi Konsep Mol siswa kelas X SMA N 8 Surakarta tahun pelajaran 2013/2014," Jurnal Pendidikan Kimia, vol. 4, no. 4, pp. 186-192, 2015.

[9] P. S. Mariati, "Pengembangan model pembelajaran fisika berbasis problem solving untuk meningkatkan kemampuan metakognisi dan pemahaman konsep mahasiswa," Jurnal Pendidikan Fisika Indonesia (JFI), vol. 8, pp. 152-160, 2012.

[10] Hayrettin, "the effect of problem posing on problem solving in introductory physics course," Journal of Naval Science and Engineering, vol. 6, no. 3, pp. 1-10, 2010.

[11] N. Nurlaila, S. and W. Sunarno, "Pembelajaran fisika dengan PBL menggunakan problem solving dan problem posing ditinjau dari kreativitas dan keterampilan berpikir kritis siswa," Jurnal Inkuiri, vol. 2, no. 2, pp. 114-123, 2013. 